\title{
Effect of Bio-Fertilizers on Mycelial Growth and Physical Properties of White Button Mushroom [Agaricus bisporus (Lange) Imbach]
}

\author{
Binit Kumar*, Chanchila Kumari and Manish Kumar
}

Indian Council of Agricultural Research-National Rice Research Institute, Central Rainfed Upland Rice Research Station, Hazaribag, Krishi Vgyan Kendra, Koderma, Jharkhand, India

*Corresponding author

\section{A B S T R A C T}

\begin{tabular}{|l|}
\hline Ke y w o r d s \\
Agaricus bisporus, \\
Pseudomonas putida, \\
$\begin{array}{l}\text { PSB, Waste tea leaf } \\
\text { and Vermicompost }\end{array}$ \\
\hline Article Info \\
\hline $\begin{array}{l}\text { Accepted: } \\
\text { 20 January } 2018 \\
\text { Available Online: } \\
\text { 10 February } 2018\end{array}$ \\
\hline
\end{tabular}

The experiment was incepted to understand the effect of bio fertilizers on enhancement of physical properties of Agaricus bisporus. The application of bio fertilizers at the time of casing gave slightly better result followed by application of bio fertilizers at the time of spawning. All the treatments of bio fertilizers i.e. Pseudomonas putida and PSB (Bacillus megaterium) either alone or in combination were found significantly effective in improving growth and yield of $A$. bisporus. The phosphate solubilizing bacteria either alone or in combination performed better as compared to Pseudomonas putida alone. The reduction in time taken for mycelium run (10.3 days), pinhead initiation (3.9 days), and maximum size of fruiting bodies $(12.4 \mathrm{~cm})$, number of fruiting bodies ( 94.3 per bag), weight $(30.1 \mathrm{~g})$, yield $(1.26 \mathrm{~kg})$ and moisture content $(89.4 \%)$, of white button mushroom after application of Pseudomonas putida and PSB (Bacillus megaterium) in cased. The microbial inoculants showed an increase of 49 per cent in yield as well and morphological characteristic when combined with Garden Loam soil, Farm Yard Manure, Waste tea leaf and Vermicompost used as a casing mixture for white button mushroom.

\section{Introduction}

Mushrooms are the asexual fruiting bodies of edible gill fungi belonging to the subdivision Ascomycotina or Basidiomycotina. Mushrooms are achlorophyllus fungi occurring seasonally during rainy days all over the world in various habitats varying from sandy plain to thick forest or green meadows to road side pathways (Adejumo and Awosanya, 2005). The mushrooms comprise a large heterogenous group having various shape, size, colour, appearance and edibility (Mishra and Shukla, 2007). The button mushroom is the most widely cultivated and consumed mushroom throughout the world and includes about $40 \%$ of total world mushroom production (Giri and Prasad, 2007). The production and the use of button mushrooms as fresh food have newly increased in India. The mushroom production in China is highest in the world while in India it was $86,900 \mathrm{MT}$, in top 10 mushroom exporting countries; India is at rank 8th in the world (FAO, 2010). The button mushroom will grow on composted substrates made from various materials but usually wheat straw supplemented with wheat bran is commonly 
used. A lot of bio- waste is being generated in rural areas and this could be utilized directly through mushroom cultivation. The cultivation of mushroom is unique in the sense that it is the most efficient and economically viable process combining mycology and biotechnological protocols for the conversion of lingo-cellulosic waste material in to high quality protein rich palatable food. The mushroom cultivation is labor intensive and provides employment opportunities especially in rural areas. Now a days, there is need to promote the cultivation of mushroom because of, increasing world population.

The ever increasing population, shrinking of agricultural land, environmental issues, water availability and quality food demands are going to be burning issues during coming decades. To meet these challenges diversification in food portfolio in areas like horticulture is of paramount importance. Utilizing these wastes for growing mushrooms can enhance income and impart higher level of sustainability (Tewari and Pandey, 2002). Undoubtedly, India has tremendous potential for the growth of agro based industries and mushroom production and processing is an emerging area with an excellent export potential.

The experimental results show that the presence of microbial population in both compost and casing soil plays vital role in $A$. bisporus cultivation. The microbial biomass present in compost affects the mycelial spread during spawn run phase, while in casing soil it triggers the induction of reproductive phase of the A. bisporus life cycle (O.P. Ahlawat and R.N. Verma, 2001). On this prosperous ground we can assumed that the mode of cultivation of white button mushroom may be modified by utilization of bio-fertilizers for getting better results in improving morphological, bio chemical characters as well as yield.

\section{Materials and Methods}

The experiment was set up in CRD deign in mushroom crop room of ICAR-NRRICRURRS-KVK, Jainagar, Koderma (Jharkhand) with four different combinations of bio fertilizers including control and it was replicated eight times. The application of Pseudomonas putida and PSB (Bacillus megaterium) either alone and in combination were tested for morphological characteristic of A. bisporus at the time of spawning and casing (Table 1).

The compost was prepared by long composting method which took 28-30 days and 8 turning (Mantel et al., 1972; Garcha et al., 1981a). For compost preparation $300 \mathrm{~kg}$ of wheat straw, Wheat bran $15 \mathrm{~kg}, \mathrm{SSP} 3 \mathrm{~kg}$, MOP $3 \mathrm{~kg}$, Urea $6 \mathrm{~kg}$, Gypsum $35 \mathrm{~kg}$, and Pesticide $150 \mathrm{ml}$ were used. The straw is thoroughly wet on clean concrete floor for 24 hr. and mixed with the wheat bran and fertilizer separately. The substrate prepared was formed into a large heap of 5 feet width and 7 feet height to encourage intense microbial activities. Turing has to be done every 3-4 days after adding water to maintain around $75 \%$ moisture and allowing passing the air and getting the aerobic conditions. Gypsum is added at 3rd turning and the compost was ready for spawning after 8th turning, it may require more turnings if the compost was not free form ammonia if not than necessary turning will be applicable until it is completely free form ammonia (Shandilya, 1988). Compost bags $(50 \times 30 \times 10 \mathrm{~cm})$ containing $10 \mathrm{~kg}$ of compost derived from wheat straw and 75 gm (Aneja, 2004) of mushroom seed inoculated with spraying of bio fertilizers at the concentration of $15 \mathrm{ml} P$. putida, $15 \mathrm{ml}$ PSB either alone and in combination $(15 \mathrm{ml} P$. putida $+15 \mathrm{ml}$ PSB) were mixed gently in compost under sterilized condition (Kapoor, 2004). After mixing of mushroom seed and inoculants the crop bags were placed in 
mushroom crop room. After complete colonization of mycelium on compost the casing applied; for casing purpose $(3-5 \mathrm{~cm})$ garden loam soil, farm yard manure, Vermicompost mixed with waste tea leaf in 2:1:1:1 proportion and Pseudomonas putida and PSB applied both solely and in combination as used at time of casing.

The cased bags were watered with hand water spray pump once or twice a day depending upon water requirement and covered by nonprinted newspaper. Necessary precautions were taken to maintain a relative humidity up to 85 percent by wetting of crop room floor and a temperature of $25.0 \pm 2^{0} \mathrm{C}$ at spawn run and $16.0 \pm 2^{\circ} \mathrm{C}$ at the time of fruiting by lightening $100 \mathrm{~W}$ bulb. The pure culture of $P$. putida, PSB (B. megaterium) and master spawn were collected from Birsa Agricultural University, Ranchi, Jharkhand and mass multiplication was done on King's B medium (composition of King's B comprises of Proteose peptone 20g, Glycerol $10 \mathrm{ml}$, $\mathrm{K}_{2} \mathrm{HPO}_{4} 1.5 \mathrm{~g}, \mathrm{MgSO}_{4} .7 \mathrm{H}_{2} \mathrm{O} 1.5 \mathrm{~g}$, Agar $20 \mathrm{~g}$ and Distilled water $1000 \mathrm{ml}$ ) (King et al., 1954) and Nutrient broth medium respectively. Dilution plate techniques were applied for counting of bacterial cells $/ \mathrm{ml}$.

White button mushrooms are harvested on the basis of maturity rather than size. In general button mushroom harvested at a stage when cap diameter is twice the length of stipe (Kohli, 1984). On the basis of maturity they are classified into three grade i.e. Grade-A at button stage, Grade-B if button allowed to grow further 'veil' to reveal pink gills known as cup and Grade-C if caps further grow in size and became fully 'open' or 'flat' exposing dark gills. Mushrooms have a very short shelflife so that's why it was placed in refrigerator (lower shelves) for study of different morphological characteristic. Total yield was determined by taking the weight of mushroom obtained after $1^{\text {st }}, 2^{\text {nd }}$ and $3^{\text {rd }}$ flush.

\section{Results and Discussion}

Present study was planned to evaluate the effect bio-fertilizers on morphological characteristic of white button mushroom as well as yield. Mushrooms are protein rich ecofriendly food and it is cultivable initially as an empirical process. But the scientific understanding of mushroom cultivation has help in improving the cultivation technology. The wide range of agricultural and urban wastes include sawdust, paddy straw, sugarcane baggage, corn stalk, corn cobs, waste cotton, leaves and pseudo stem of banana, water hyacinth, duck weed and rice straw were suggesting by many workers to grow different edible mushroom because it does not require costly processing method besides enrichment material (Stanley et. al., 2011). Peat moss is mainly used as casing in most of the countries but, in India, FYM + loam soil is commonly used as casing for the production of A. bisporus. Maximum yield of A. bisporus in casing combination of farm yard manure + Vermicompost leached + three years old spent compost in the already spawn run compost was reported by Shandilya (2002).

The combination of FYM + GLS (1:1) is used as a standard casing material in India for the cultivation of A. bisporus. Processed municipal waste has also been tested as a casing substrate for A. bisporus by Jarial and Shandilya (2002a) and Jarial et al., (2005). In addition to these findings we went to one step ahead to minimize the cost of cultivation as well as trying improving quality of $A$. bisporus by using bio-fertilizer. The casing mixture plays a vital role in development of uniform fruiting bodies and also open a broad way to take a chance to modified its characteristic with different materials which has been possess idol characters for casing (Kumar et. al., 2017) (Fig. 1-6). 
Fig.1 Wetting of wheat straw. Fig.2 Construction of compost pile. Fig.3 Taking compost temperature. Fig.4 Transfer of spawned compost bag in crop room. Fig.5 Pin head stage of

Fruiting bodies. Fig.6 Fruiting bodies of Agaricus bisporus
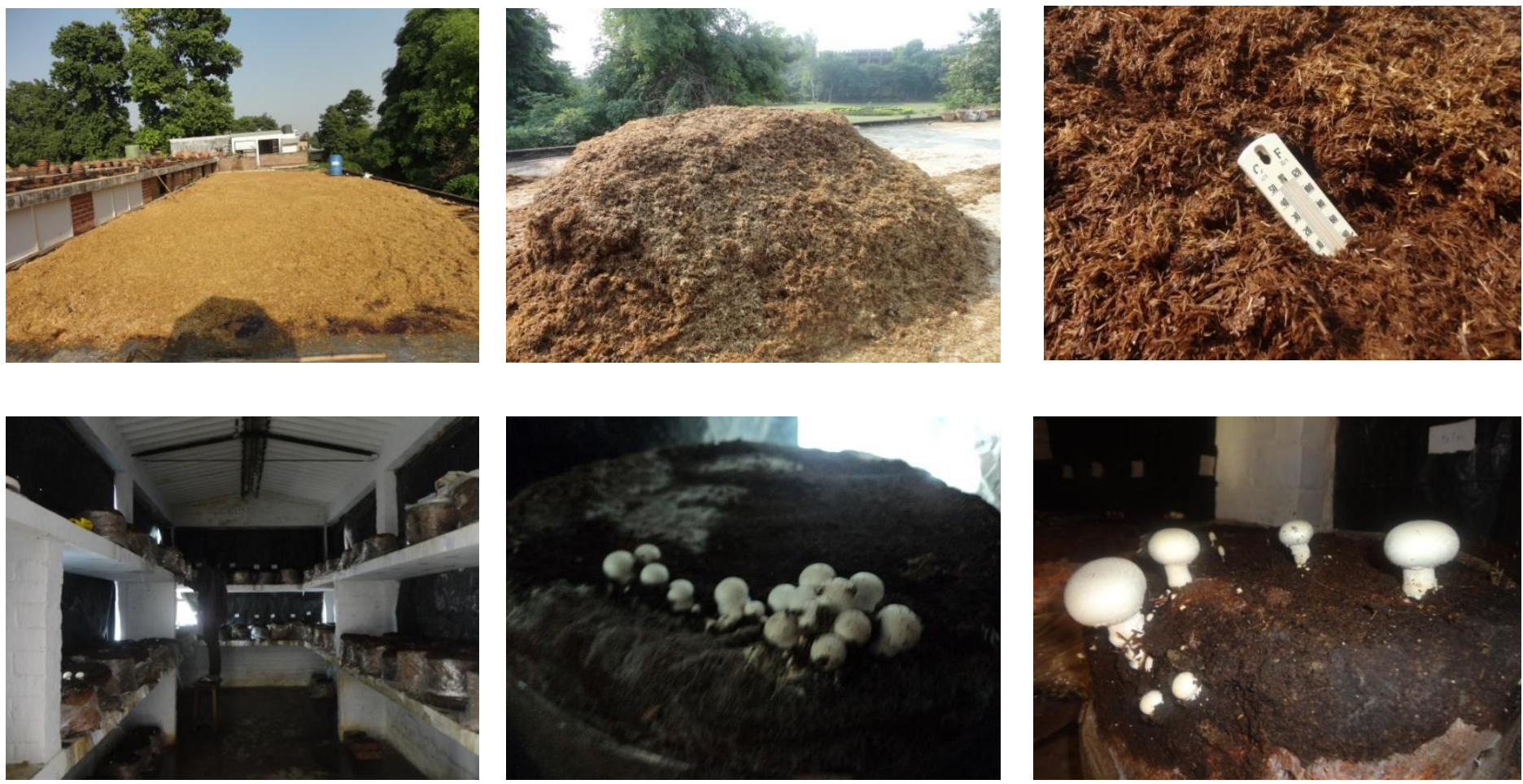

Table.1 Detail of treatment combination

\begin{tabular}{|c|c|}
\hline S.N & Treatment combination \\
\hline $\mathbf{T}_{\mathbf{0}}$ & GLS+FYM+VC+ waste tea leaf $(2: 1: 1: 1)$ \\
\hline $\mathbf{T}_{\mathbf{1}}$ & GLS+ FYM+VC+ waste tea leaf $(2: 1: 1: 1)+P$. putida $\left(10^{8}\right.$ c.f.u./ml $) 15 \mathrm{ml}$ per kg compost \\
\hline $\mathbf{T}_{\mathbf{2}}$ & GLS+ FYM+ VC+ waste tea leaf $(2: 1: 1: 1)+$ PSB @ $15 \mathrm{ml}$ per kg compost \\
\hline $\mathbf{T}_{3}$ & GLS+ FYM+ VC+ waste tea leaf $(2: 1: 1: 1)+P$. putida $\left(10^{8}\right.$ c.f.u. $\left./ \mathrm{ml}\right)+$ PSB $(1: 1) @ 30 \mathrm{ml}$ \\
& per kg compost
\end{tabular}

Table.2 Effect of bio fertilizers on physical properties of Agaricus bisporus at the time of spawning

\begin{tabular}{|c|c|c|c|c|c|c|c|c|}
\hline S.N & Treatment combination & MR & PI & NFB & $\mathbf{F S}(\mathrm{CM})$ & $\mathbf{W}(\mathrm{g})$ & Yield(Kg) & MC\% \\
\hline$T_{0}$ & GLS+ FYM+VC+ waste tea leaf $(2: 1: 1: 1)$ & 19.6 & 10.2 & 56.8 & 5.2 & 8.1 & 0.65 & 66.2 \\
\hline $\mathbf{T}_{1}$ & $\begin{array}{c}\text { GLS+ FYM+VC+ waste tea leaf }(2: 1: 1: 1)+P . \\
\text { putida }\left(10^{8} \text { c.f.u. } / \mathrm{ml}\right)\end{array}$ & 17.3 & 9.3 & 71,3 & 7.1 & 9.7 & 0.73 & 65.1 \\
\hline $\mathbf{T}_{2}$ & GLS+ FYM+ VC+ waste tea leaf $(2: 1: 1: 1)+$ PSB & 15.2 & 7.6 & 76.4 & 8.3 & 13.8 & 0.81 & 74.7 \\
\hline $\mathbf{T}_{3}$ & $\begin{array}{c}\text { GLS+ FYM+ VC+ waste tea leaf }(2: 1: 1: 1)+P . \\
\text { putida }\left(10^{8} \text { c.f.u. } / \mathrm{ml}\right)+\mathrm{PSB}\end{array}$ & 13.7 & 6.5 & 83.2 & 10.6 & 18.2 & 0.88 & 85.1 \\
\hline
\end{tabular}

MR: minimum days required for mycelium run, PI: Pin head initiation, NFB: Number of fruiting bodies, FS:

Fruiting size, W: weight, MC: Moisture content 
Table.3 Effect of bio fertilizers on physical properties of Agaricus bisporus at the time of casing

\begin{tabular}{|c|c|c|c|c|c|c|c|c|}
\hline S.N & Treatment combination & MR & PI & NFB & $\mathrm{FS}(\mathrm{CM})$ & $\mathbf{W}(\mathrm{g})$ & Yield(Kg) & MC\% \\
\hline $\mathbf{T}_{0}$ & GLS+ FYM+VC+ waste tea leaf $(2: 1: 1: 1)$ & 19.6 & 10.2 & 56.8 & 5.2 & 8.5 & 0.65 & 66.2 \\
\hline $\mathbf{T}_{1}$ & $\begin{array}{c}\text { GLS+ FYM+VC+ waste tea leaf }(2: 1: 1: 1)+P . \\
\text { putida }\left(10^{8} \text { c.f.u. } / \mathrm{ml}\right)\end{array}$ & 15.2 & 7.2 & 79.2 & 7.9 & 12.4 & 0.91 & 79.2 \\
\hline $\mathbf{T}_{2}$ & GLS+ FYM+ VC+ waste tea leaf $(2: 1: 1: 1)+$ PSB & 13.6 & 5.9 & 83.5 & 9.3 & 16.8 & 1.02 & 83.1 \\
\hline $\mathbf{T}_{3}$ & $\begin{array}{c}\text { GLS+ FYM+ VC+ waste tea leaf }(2: 1: 1: 1)+P . \\
\text { putida }\left(10^{8} \text { c.f.u. } / \mathrm{ml}\right)+\mathrm{PSB}\end{array}$ & 10.3 & 3.9 & 94.3 & 12.4 & 30.1 & 1.26 & 89.4 \\
\hline
\end{tabular}

MR: minimum days required for mycelium run, PI: Pin head initiation, NFB: Number of fruiting bodies, FS: Fruiting size, W: weight, MC: Moisture content

Kept all these necessary possible factors in mind the combination of garden loam soil, farm yard manures, waste tea leaf and Vermicompost were taken for casing in proportion of 2:1:1:1. When the data depicted in table 2 and 3 were combined to see the effect of bio-fertilizers on morphological characters of $A$. bisporus at the time of spawning and casing. We found that the minimum days required for complete mycelium run 13.7 (10.3), pin head initiation 6.5 (3.9), number of fruiting bodies per bag 83.2 (94.3), maximum button size 10.6 (12.4) maximum yield 0.88 (1.26) and maximum moisture content 85.1 (89.4) were recorded. All the observation for physical parameters of A. bisporus was found significantly different from other stages of application of biofertilizers either solely or in combinations over control (Table 2 and 3).

Physical and chemical parameters of the casing are play a major role in development of congenial environmental condition for growth of microbial population in casing layer. Additionally, if already spawn run compost is added to casing, it increases the yield. Sporophores formation in basidiomycetes is a complex phenomenon triggered by physiological and biochemical factors in the substrate and in the mushroom mycelium. The sporophores formation is usually correlated with the nutritional status of the casing, Carbon dioxide: Oxygen ratio, temperature, relative humidity of the crop room and the co-factor or co-enzymes activating the enzymatic system of the mushrooms. The relevance of microbiological factors is not limited to fruiting; existing microbes exert unique interactive behaviors with unique mechanisms involving various types of metabolites on mushrooms. Mushroom fungi in general produce organic acid reduce the $\mathrm{pH}$ of substrate (Zadrazil and Schaeidereit, 1972), which favors the spread of mycelia only. The $\mathrm{pH}$ of casing media however decreases with progress of crop due to accumulation of various salts (Shandilya and Hayes, 1987). Grewel and Rainey (1991) demonstrated the migration of $P$. fluroscent towards mcelial exudates of A. bisporus which assisted in subsequent colonization and proliferation which appears necessary before the bacteria can provide A. bisporus with the stimulus to initiate basidiom formation. Miller et al., (1995) observed adherence of pseudomonas cell hyphal walls of $A$. bisporus. Some other literature supports the role of bio-fertilizer in formation of fruiting bodies in A. bisporus is followed Singh et al., (2013), Murmu et al., (2014) and Kumar et al., (2017).

\section{References}

Adejumo, T. O. and Awosanya, O. B. 2005. Proximate and mineral composition of four edible mushroom species from South Western Nigeria. Afri. J. Biotech. 4(10):1084-1088. 
Ahlawat O.P. and Verma, R. N. 2001. Invitro interactions studies between bacteria and Pleurotus: a tool for differentiating Pleurotus spp. and selecting fruiting including bacterium. In: proc. of Int. Conf. On New Horizons in 78 Biotechnology. April, 18-22, 2001, RRL, Thiruvananthapuram, India. pp. 78 (abstract).

Aneja, K. R. 2004. Experiments in Microbiology, Plant Pathology and Biotechnology. $4^{\text {th }}$ edition, New age International (P) limited, Publisher. 506-514.

FAO (Food and Agriculture of United Nation) 2010. World Mushroom and truffle: United Nation, FAO Stat. 55: 566-575.

Garcha, H.S., Sekhar, A. and Phulela, R. P. 1981a. Utilization of Agri wastes for Mushroom cultivation in India Mush. Sci., 11(1): 245-254.

Giri, S.K. and Prasad S. 2007. Drying kinetics and rehy- dration characteristics of microwave vacuum and convective hotair dried mushrooms. Journal of Food Engineer- ing, 78, 512-521.

Grewal, S.I.S. and Rainey, P. B. 1991. Phenotypic variation of Pseudomonas putida and $P$. Tolassii affects the chemotactic response to Agaricus bisporus mycelia excludates. J. Gen. Microbiol. 137: 2761-2768.

Jarial R. S., Sandilya, T. R. and Jarial, K. 2005. Casing in mushroom beds- A Review. Agric. Rev., 26 (4): 261-271.

Jarial, R. S and Shandilya, T.R. 2002a. In Symp. "Integrated plant Disease Management through Eco Friendly Strategies" Nov., 2002, PAU, Ludhiana.

Kapoor, J. N. (2004). Mushroom cultivation. Department of Mycology and Plant Pathology, IARI, New Delhi, 14-15.

Kohli, M.S. 1984. Judging when to pick an mushroom: An aid to picker, Mushroom J., 138: 207-209.
Kumar, B., Kumari, C., Kumar, M. and Singh, V K. 2017. Conversion of agricultural by Products: Mushroom cultivation, IJCSR. 3(10): 2454-5422.

Kumar, B., Kumari, C., Kumar, M. and Singh, V K. 2017. Effect of waste tea leaf and slake lime in casing mixture on yield of white button mushroom Agaricus bisporus (Lange) Imbach]. IJCSR. 3(11): 1452-1457.

Mantel, E. F. K., Agarwala. R.K. and Seth, P.K. 1972. A guide to mushroom cultivation. Ministry of Agril. Farm Information Unit, Directorate of Extesion, New Delhi, Farm Bulletin. No. 2.

Millar, N., Gillespic, J.B. and Doyle, O.P.E. 1995. The involvement of $\mathrm{m}$ microbiological components of peat based casing materials in fructification of A. bisporus. Mushroom Sci. xiv: 313321.

Mishra, R. S. and P. K. Shukla 2007. Effect of weather variable on contamination of oyster mushroom spawn. Ann. Pl. Protec. Sci. 15: 272-273.

Murmu, R., Abhilasha A. Lal, Kumar B., Singh S. and Simon S. 2014. Incidence of Papulaspora byssina (brown plaster mould) on casing mixture and compost of white button mushroom (Agaricus bisporus), The Bioscan, 9(1): 449-451.

Shandilya, T. R. 2002.In Indian Mushroom conference, TNAU, Coimbatore, March 2002.

Shandilya, T.R. 1988. Polythene sacks or wooden trays for growing white button mushroom. Imdian Hort. 33 (2): 4 - 5.

Shandilya, T.R. and Hayes, W.H. 1987. Available elements in some casing soils. Indian Mush. Sci., 2: 10 - 15.

Singh, S., Abhilasha, A. Lal, Simon, S and Kumar B. 2013. Effect of Pseudomonas putida and casing material on growth and yield of white button Mushroom. Ann. PL. Protec. Sci. 21(2): 416-462. 
Stanley, H.O., Umolo, E.A., Stanley, C.N. 2011. Cultivation of oyster mushroom (Pleurotus pulmonarius) on amended corncob substrate. Agri. Biol. J. North America, 2(8): 1239 -1243.
Tewari, R.P. and Pandey M 2002. The Hindu survey of Indian Agriculture, pp.165167.

Zadrazil, F. And Schaeidereit, M. 1972. Die Grundlagen Fur die Inkulturnahme einerbisher nicht kultivierten Pleurotus Art. Champignen, 12: 25-32.

\section{How to cite this article:}

Binit Kumar, Chanchila Kumari and Manish Kumar. 2018. Effect of Bio-Fertilizers on Mycelial Growth and Physical Properties of White Button Mushroom [Agaricus bisporus (Lange) Imbach]. Int.J.Curr.Microbiol.App.Sci. 7(02): 2216-2222. doi: https://doi.org/10.20546/ijcmas.2018.702.267 